3. Russell JA, Navickis RJ, Wilkes MM. Albumin versus crystalloid for pump priming in cardiac surgery: meta-analysis of controlled trials. J Cardiothorac Vasc Anesth. 2004;18:429-37.

4. Lange M, Ertmer C, Van Aken H, Westphal M. Intravascular volume therapy with colloids in cardiac surgery. J Cardiothorac Vasc Anesth. 2011;25: 847-55.

5. Bellomo R, Morimatsu H, Presneill J, French C, Cole L, Story D, et al. Effects of saline or albumin resuscitation on standard coagulation tests. Crit Care Resusc. 2009;11:250-6.

http://dx.doi.org/10.1016/ j.jtcvs.2012.09.048

\section{AORTIC ARCH INTERRUPTION WITHOUT DUCTUS ARTERIOSUS AND NO VENTRICULAR SEPTAL DEFECT}

\section{To the Editor:}

We read the interesting case report by Cazavet and associates ${ }^{1}$ on "an infant with a previously unrecorded type of aortic arch interruption." However, similar types of aortic arch interruption without ductus arteriosus and without ventricular septal defect, although rare, have been previously described since $1964 .^{2-6}$ The common features of these unusual patients were the longevity up to adolescence with no severe symptoms and the presence of extensive collateral circulation supplying the descending aorta. ${ }^{2-6}$ Surgical treatment was also reported in relation to the various anatomic patterns. ${ }^{2-6}$ In the field of pediatric cardiology, sometimes some old scientific papers can represent important sources of knowledge.

The interesting new aspect described by Cazavet and associates ${ }^{1}$ is the association with del 22q11 and the relative embryogenetic implications that expand the spectrum of cardiovascular defects of this syndrome.

Carolina Putotto, MD

Marta Unolt, $M D$

Dario Marino, MD

Department of Pediatrics

"La Sapienza” University

Rome, Italy

\section{References}

1. Cazavet A, Seguela PE, Acar P, Leobon B. A new type of aortic arch interruption without significant patent ductus arteriosus and with no ventricular septal defect. J Thorac Cardiovasc Surg. 2012;143:237-9.

2. Pillsbury RC, Lower RR, Shumway NE. Atresia of the aortic arch. Circulation. 1964;30:749-54.

3. Morgan JR, Forker AD, Fosburg RG, Neugebauer MK, Rogers AK, Bemiller CR. Interruption of the aortic arch without a patent ductus arteriosus. Circulation. 1970;42:961-5.

4. Judez VM, Maitre MJ, De Artaza M, De Miguel JM, Valles F, Marquez J. Interruption of aortic arch without associated cardiac abnormalities. Br Heart J. 1974;36:313-7.

5. Dische MR, Tsai M, Baltaxe HA. Solitary interruption of the arch of the aorta. Clinicopathologic review of eight cases. Am J Cardiol. 1975;35:271-7.

6. Sharratt GP, Carson P, Sanderson JM. Complete interruption of aortic arch, without persistent ductus arteriosus, in an adult. Br Heart J. 1975;37:221-4

http://dx.doi.org/10.1016/ j.jtcvs.2012.08.076

\section{RECOGNITION AND \\ MANAGEMENT OF \\ HEPARIN-INDUCED \\ THROMBOCYTOPENIA IN \\ PATIENTS AFTER CARDIAC \\ SURGERY \\ To the Editor:}

In a recent publication, Demma, Paciullo, and Levy ${ }^{1}$ evaluated the recognition and treatment of heparininduced thrombocytopenia (HIT) in patients after cardiothoracic surgery using the direct thrombin inhibitor (DTI) argatroban. We agree that the detection and management of HIT in patients who have had cardiac surgery is of clinical importance, and we have

TABLE 1. Characteristics of patients treated with bivalirudin after cardiac surgery

\begin{tabular}{lcc}
\hline & $\begin{array}{c}\text { Before } \\
(\mathbf{2 0 0 4 - 2 0 0 6 )}\end{array}$ & $\begin{array}{c}\text { After } \\
\mathbf{( 2 0 0 7 - 2 0 1 0})\end{array}$ \\
\hline Thrombocytopenia & $15.1 \%$ & $14.5 \%$ \\
& $463 / 3065$ & $476 / 3288$ \\
DTI use in patients with thrombocytopenia & $17.5 \%$ & $23.1 \%$ \\
HITTS (per decreased platelets) & $81 / 463$ & $110 / 476$ \\
HITTS (per total adult patients) & $4.3 \%$ & $5.5 \%$ \\
HITTS mortality & $20 / 463$ & $26 / 476$ \\
& $0.7 \%$ & $0.8 \%$ \\
\end{tabular}

Thrombocytopenia is defined as a $50 \%$ decrease in platelets from preoperative baseline by 24 hours after cardiopulmonary bypass. Mortality is defined as death within index admssion. DTI, Direct thrombin inhibitor; HITTS, heparin-induced thrombocytopenia and thrombosis syndrome. used a similar method of HIT identification and treatment with the DTI bivalirudin.

Our familiarity with the use of bivalirudin was heightened after our participation in the CHOOSE-ON trial published in 2007, which evaluated the use of this DTI during cardiopulmonary bypass in patients having cardiac surgery. ${ }^{2}$ Since then, we have standardized our method of identifying HIT patients postoperatively and treating them with bivalirudin. To detect HIT, we use a method similar to that of Demma, Paciullo, and Levy ${ }^{1}$ in which patients who score in the moderate range on the 4-Ts schema ${ }^{3}$ are subjected to a platelet factor 4/ heparin immunoassay. Occasionally, we will also confirm the diagnosis with a serotonin release assay. To then distinguish HIT from hemodilution or other causes of thrombocytopenia, we also categorize the patterns of platelet counts as outlined by Pouplard and colleagues. ${ }^{4}$

Our standardization of detection methods did not alter the number of patients who received a diagnosis of HIT (14.5\% compared with $15.1 \%$ before 2007). However, we did see an increased rate in the use of bivalirudin to treat thrombocytopenia (23.1\% compared with $17.5 \%)$ (Table 1). This suggests that our standardization procedures may have resulted in earlier identification and medical management of HIT. 